\title{
アメフラシ摂食行動における動機づけニューロンと その周辺ネットワーク
}

\begin{abstract}
徳島大学菌学部 長 濱 辰 文
Food stimili elicit a characteristic "feeding posture", in which the animal lifts the head and relaxes the anterior part of the foot. A pair of cerebral neuron, C-PR, may function as an important element that evokes a food-arousal state. The C-PR may also mediate the feeding posture by exciting or inhibiting many types of body postural motor neurons. In addition, it has longlasting modulatory effects on the movements of the neck and the anterior foot, which were produced by the motor neurons. These effects may be caused by modulatory neurons receiving monosynaptic excitatory inputs from the C-PR.
\end{abstract}

Aplysia/Feeding behavior/Appetitive response/Posture/Command neuron/Modulatory neuron

\section{1.はじめに}

行動心理学の分野で行動の動機づけ（Motivation） という言葉がある．摄食行動を例にとると，食物を目 の前に置かれるといつもロを動かして食べるかという とそうではなく，内的生理条件によって大きく影翌さ れる. 私達でもそうであるが, なんでもない時におい しそうな匂いが漂ってくると急に空腹感をおはえる. この時，目の前に食物がでてくれば誰でもそれを食べ るであろう．この時の“おいしそうな勾い”が摃食行 動の “動機づけ”である.この状態は摄食の蕉備段階 であり，食べる前から掑食に備えて唾液，胃液などの 分泌が促進され，また血圧の変化もみられる. また， 時には我を忘れて他のことに手がつかないかもしれな い.すなわち他の行動が抑制されてしまうのである.

最近，海産の軟体動物アメフラシ（Aplysia）でま さにこのような摃食行動の動機づけを担うと考えられ るニューロン (C-PR) がコロンヒア大学医学部の Kupfermann 研究室で見出されだ．そこでここでは, このニューロンを中心とする神経回路網について明ら かになったところを紹介したい.

Neural control of Aplysia feeding posture by the food-arousal neuron C-PR.

Tatsumi NAGAHAMA

Department of Physiology, School of Dentistry, Tokushima University

\section{2. アメフラシの摄食行動}

アメフラシのいる水槽に食物の海草を入れると，し ばらくして動物はいっせいに首をもたげ, 腹足の前の 部分を大きく広げる.これは摄食姿势（Feeding posture, 図 $1 \mathrm{~A}$ ) と呼ばれ，搨食行動の開始時にみら れる特徵的なポーズである゙2.この時, 動物の体内で は血液循環系が活性化され，心拍数は増大する．また 他の行動，例えば頭やえらのひっこめ反射などが抑制 を受ける゙3.このような状態は椇食の準備段階であり， これらの応答を Appetitive response と呼んでいる. その後，近くに食物があれば前足部でそれをつかみ攝 食を開始する.この時, まずリズミカルなロおよび画 舌の運動により食物を口腔内へ捸取し（Biting），そ の後、咽頭部のみのリズミカルな運動により食物を食

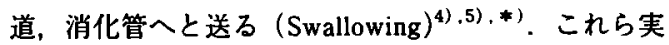
際の掑食応答を Consummatory response と呼び, アメ フラシの捸食行動は前後二段階に分けることができる。 Consummatory responseにおける神経回路網も最近か なり明らかになってきたが(6)-10)、12)，ここでは前半の Appetitive response の回路網を取り扱うことにする.

*) Biting. Swallowing の定義は日本産（Kurodai）とアメ リカ産 (califomica) で異なる．アメリカ産では倉物な しでおころ口の動きを Biting，食物を食べている時の それを Swallowing としている。 
A

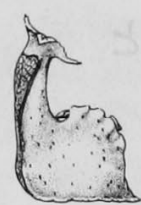

B

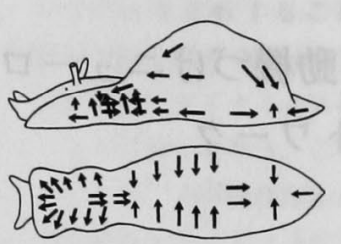

图1、アメフラシにおける提食姿警（A）とC-PR 故電に より誘発される類似の運動 (B)

\section{C-PR ニューロン}

アメフラシの神䅅系は主に 5 種類の神経節からな $ろ^{11)}$ が, C-PR 二ューロンの細胞体は最も上位中枢で ある Cerebral ganglion 内に左右一つずつ見出されだ． 匂いを感じる触覚部を海草，もしくはその抽出液で刺 激すると C-PR は放電を開始する，一方，C-PR は非 常に多数のニューロングループに影幚を与えることも わかった（図 2 ）。ますC-PRの放電は，循環系の心 拍数増大に関与する調節ニューロン（RB $\mathrm{RE}_{\mathrm{HE}}, \mathrm{L} 10 ）$ を 興唼させた。また，C-PR は頭やえらを引っ込める運 動ニューロン（Bn，L7）の放電を抑制した。さらに は摄食 Biting 応答の指令ニューロン $(\mathrm{CBI}-2)^{12)}$ や調
節ニューロン $(\mathrm{MCC})^{13)}$ を弱く興拿させ，引き続いて 起こる摄食が発現しやすい状況を形成することもわ かった.これらの結果は C-PR が搨食行動の動機づけ に大きく奇与していることを示唆する.

\section{C-PR ニューロンによる摄食姿势の形成}

C-PR は主に体の運動に関与する Pedal ganglion 内 の多数のニューロンへも影製を与えた. そこで，筆者

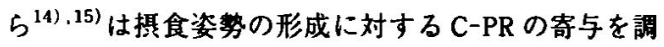
ベてみた. 実験では体の各部を支配する運動ニューロ ンをまず同定し，C-PRからのシナブス入力を調べた. 結果を表 1 に示す，首（Neck）, 腹足（Foot）, 体側 (B. Wall, Parapodia) と, 体のいろいろな部分を支 配する多数の運動ニューロン（ $\mathrm{NK}_{\mathrm{t}}, \mathrm{AF}_{\mathrm{t}}, \mathrm{MF}_{\mathrm{t}}$ など） 八両側性に情報を送っている．中でも首部を支眍する 運動ニューロンでは C-PR の放電により大きく興奪さ せられた。一種類のニューロン $\left(\mathrm{NK}_{\mathrm{t}}+\mathrm{MF}_{\mathrm{t}}\right)$ では単 シナプス性の興恋性シナプス後電位（EPSP）も誘発 された。一方，前腹足部 (Foot-ant) を支配する運動 ニューロンでは，ほとんどの場合 C-PRにより抑制性 シナプス後電位（IPSP）が誘発され，放電が抑制さ れた。さらに，体の片側からなる semi-intact な材料

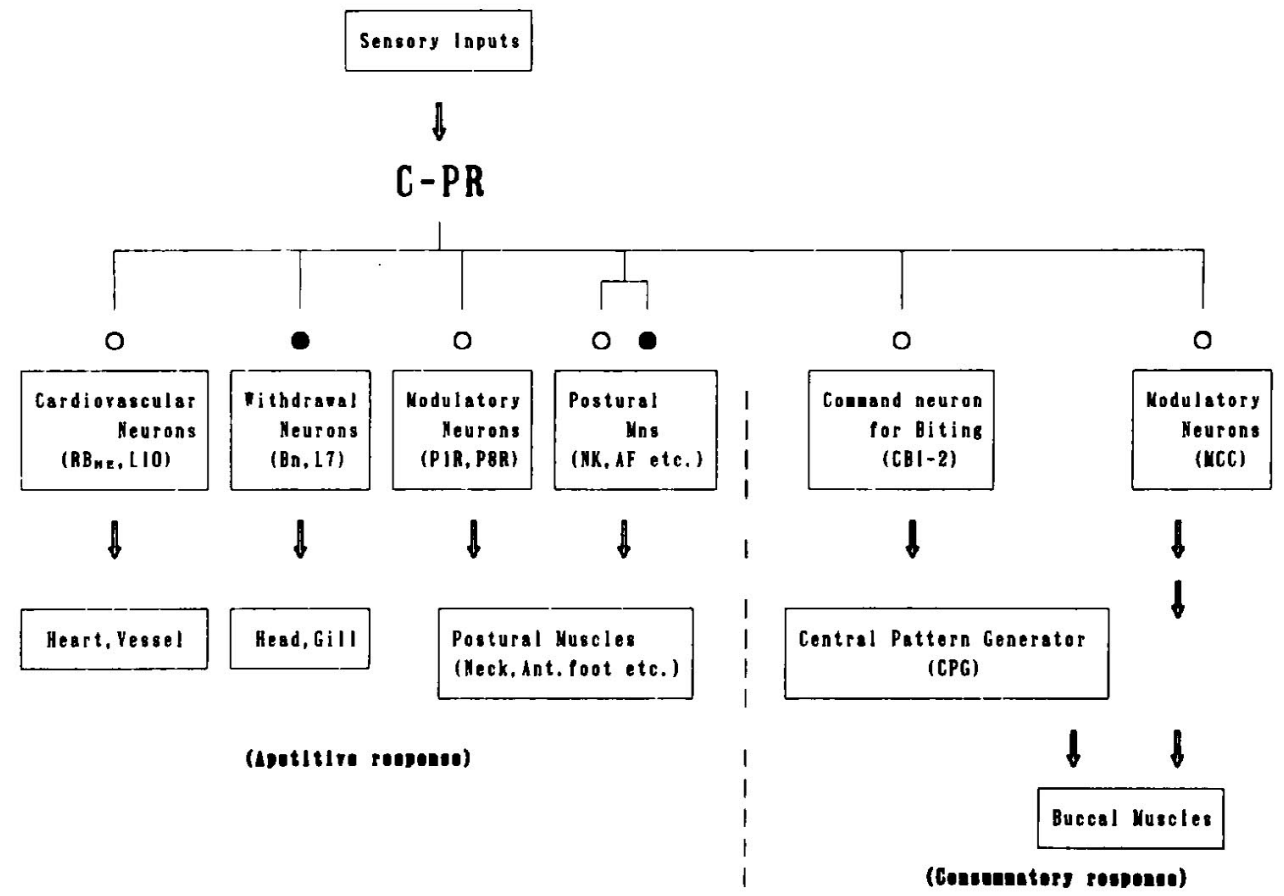

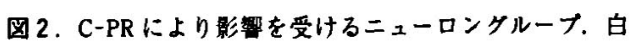
丸は興筫性，黑丸は抑制性入力を示す。 


$$
\text { アメフラシ摄食行動における動機づけニューロンとその周辺ネットワーク }
$$

表 1.C-PR から体各部を支配する運動ニューロンへのシ ナブス入力. EPSP, IPSPはそれぞれ興高性、㧕制 性シナブス後電位. elPSP は初期の弱い興畫とそれ に秸く大きな抑制性シナブス後電位. None は入力 なし. 表の数字は同定運動ニューロンの数を示す. 運佫ニューロン名の添字はそれぞれ動物の前後 (1). 横方向 $(\mathrm{t})$ の運動を誘発する。また，広い領域を 支配するものは+記号で表した。例えば, $\mathrm{NK}_{\mathrm{t}}+$ $\mathrm{MF}_{\mathrm{t}}$ は首と腹足中央部を支配し、横方向の逜動を誘 発する. ant., 前部; mid., 中央部; B. Wall, 体㑡. 1) C-PR からの入力はほとんどが多シナブス性で あったが、この運助ニューロンでは単シナプス性入 カも見られた.

\begin{tabular}{|c|c|c|c|c|c|}
\hline \multirow{2}{*}{$\begin{array}{l}\text { Ijpo of } \\
\text { Yater lieurons }\end{array}$} & & \multicolumn{2}{|c|}{ Syaptio lapu } & at froe & \multirow{2}{*}{$\frac{\text { C-PR }}{\text { Mone }}$} \\
\hline & & EPSP & - IPSP & IPSP & \\
\hline \multirow[t]{4}{*}{ Meck } & $\mathrm{HK}$, & 2 & & & \\
\hline & $N K_{1}+K F_{2}{ }^{\prime \prime}$ & 1 & & & \\
\hline & $N K_{1}+T_{B_{1}}$ & 1 & & & \\
\hline & NK. & 4 & & & 1 \\
\hline \multirow[t]{3}{*}{ Foot-ant. } & $A F_{2}$ & 1 & 1 & 3 & \\
\hline & $A F$ & & 3 & 1 & \\
\hline & $A F_{2}, 1$ & & 1 & 1 & \\
\hline \multirow[t]{3}{*}{ Foot-aid. } & $M F_{\downarrow}$ & 2 & & & 1 \\
\hline & $M F_{2}+T F_{2}$ & 2 & & & \\
\hline & $M F_{1}$ & & & 2 & 1 \\
\hline \multirow[t]{4}{*}{ Foot-tail } & $\mathrm{TF}_{\mathrm{e}}$ & 2 & & & 1 \\
\hline & $T F_{1}$ & 1 & & & 1 \\
\hline & $T F_{1}+T B_{1}$ & 1 & & & \\
\hline & $T F_{2} \ldots$ & 2 & & & 1 \\
\hline \multirow{2}{*}{ B. Nall-tail } & $T B_{2}$ & 2 & & & 2 \\
\hline & TB, & 4 & & & \\
\hline \multirow[t]{2}{*}{ Parapodia } & $\mathrm{PP}_{2}$ & 2 & & & 1 \\
\hline & $\mathrm{PP}_{1}$ & 1 & & 1 & 1 \\
\hline
\end{tabular}

を用いた実験より，左右あるC-PRのどちらか一個の 放電だけで，図 1 A の摃食姿势に非常に類似するポー ズをとるような運動（因1B）が体各部に誘発される こともわかった15),16).これらの結果，C-PR は提食 姿势の指令ニューロンとしても寄与していると考えら れる。

\section{C-PRによる姿势保持}

さらに，運動ニューロンにより誘発される体各部の 運動は，C-PR 短時間放電させるとその大きさが修 飾されることも明らかになった C-PR の放電後，その運動は大きく增强させられた。 一方, 前腹足部では動きの方向により異なった効果が 発現した（図3).すなわち動物の前後方向の動きは 增强，もしくは初期の小さな抑制後大きく增強させら れた。これに对し横方向の動きは常に抑制された。 れらC-PRによる効果は增强のほうが抑制より長期 （100-200秒）に持続する傾向が見られた。表 2 に体 各部の運動に対する C-PRの効果をまとめた。 首, 前 腹足部以外の運動に対する効果は非常に小さい。 C-PRによる首部運動の增强は，掑食姿勢における頭 上げの增強保持に，また前腹足部の横方向の運動抑制 はこの部分を広げる掑食姿勢の保持にそれぞれ寄与す ると考元られる. さらに前腹足部の前後方向の運動增 強はこの部分の横搪張をより大きくする。このように C-PR は各運動ニューロンに情報を送り掑食姿熬を形 成すると同時に，それらの動きを長期に修飾すること
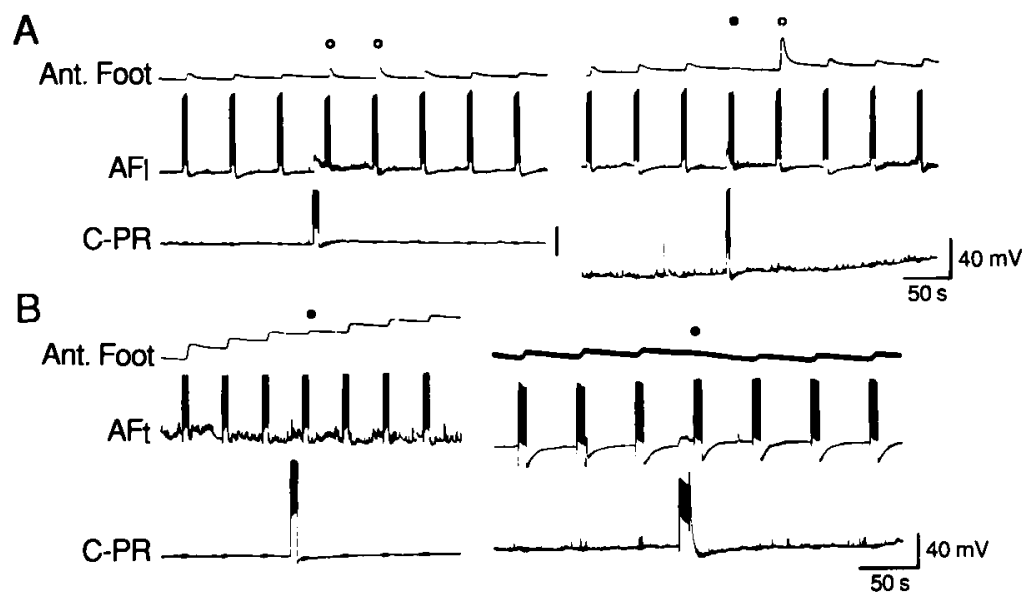

图 3. 運動ニューロン $\left(A F_{1}, A F_{1}\right)$ によって誘発された前腹足運動（Ant. Foot）へのC-PR の增強， 抑制効果 (白, 黑丸部). A は前後方向，B は横方向の運動. 実験では運動二ューロンの放電 の頿度および時間を一定とした。 
表 2. 運動ニューロンによって誘発された体各部の運動に 対するC-PRの增強（E), 抑制 (D) 効果. 小文字 は弱い奻果，0は奻果なしを表す. Transverse は 横方向の運動, Longitudinal は前後方向の運動.

\begin{tabular}{lll}
\hline Rogion & Type of Movenents & C-PR offect \\
\hline Neck & $\begin{array}{l}\text { Transverse } \\
\text { Longitudinal }\end{array}$ & $E$ \\
Foot-ant. & Transverse & D \\
& Longitudinal & E or dE \\
Foot-mid. & Transverse & 0 or e \\
& Longitudinal & 0 \\
Foot-tail & Transverse & 0 or e \\
& Longitudinal & 0 or d \\
B. Nall-tail & Transverse & 0 \\
& Longitudinal & 0 \\
Parapodia & Transverse & 0 \\
& Longitudinal & 0 \\
\hline
\end{tabular}

によりその姿势を保持させると考えられる.

\section{6. 運動調節ニューロン}

C-PRはその形態上，末梢の筋へは直接軸索を伸ば していない.そこで，C-PRによる運動增强，抑制効 果は何らかの運動調節ニューロンを介していると考え
られる。我々は C-PRより単シナプス性 EPSPを受け, 首, および前腹足部の運動を直接調節する 3 種類の介 在ニューロンをPedal ganglion 内に見出した ${ }^{16), 17)}$. それらのうち 2 種類は前腹足部の運動調節に関与し, その機能により P1R-E, P1R-D と名付けた。.また，残 り 1 種類は首部の運動調節に関与し $\mathrm{P} 8 \mathrm{R}$ とした.

P1R-E はその放電により前腹足部の前後方向の動 きを增強した（図4A）。またこのニューロンの放電 は横方向の動きにはほとんど影響を与えなかった（図 4B). 一方，P1R-D はその放電により，前腹足部の前 後，横方向の動きをともに抑制した（図 5 ）. また, C-PR を長期に高頻度で放電させた場合，P1R-E はそ の間および後も放電を継続するが，P1R-D は初期の みに放電し，すぐに放電を停止する傾向が見られた。 この結果，C-PRの効果で增強のほうが㧕制よりも長 期に持続することが説明された．またこのことは，前 腹足部の前後方向の運動に対する C-PR の効果も説明 した.すなわちこの種の運動へは PIR-E, P1R-D とも に妨果を持つため, 前述のようにC-PR を放電させる としばしば初期の抑制後大きな增強効果が見られた (図3A 右)。一方, 首部の運動調節は単純であり P8R 一種類のニューロンの放電により前後, 横方向共にそ の運動は增強させられた。

これら運動調節ニューロン一個の放電効果は C-PR 放電時のそれに比べるとかなり小さく，複数個の同種
$A_{1}$

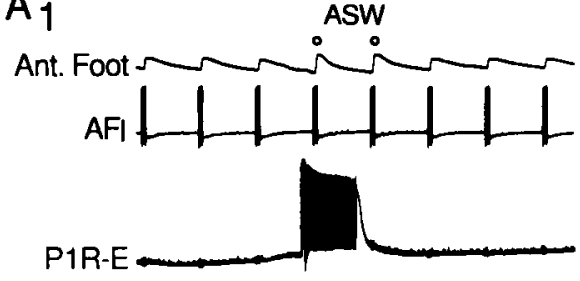

2

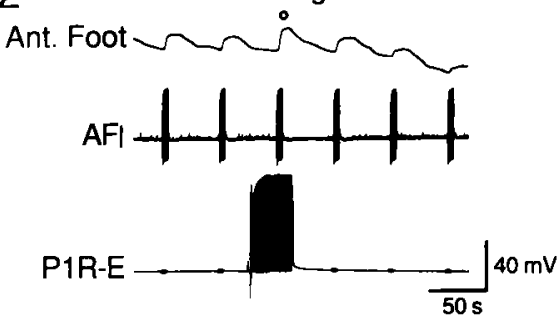

B

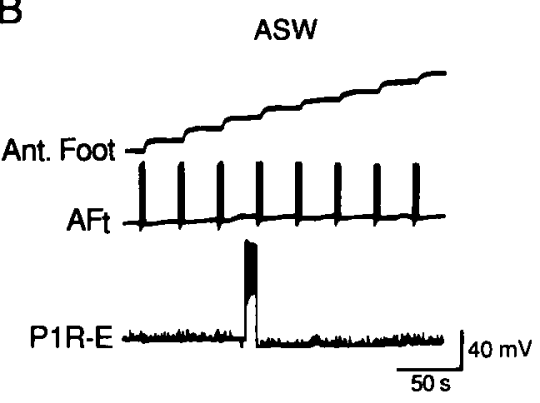

图 4.調節ニューロンP1R-Eによろ前腹层運動（前後方向，Ant. Food）の增強効果 (Aの白丸部). この增强は高マグネシウム楁液 $\left(\mathrm{HiMg}^{++}\right)$で中枢内シナブス結合を抑えた場合 $\left(\mathrm{A}_{2}\right)$ 6発現 し，ニューロンが筋に直接作用すると考えられる．ASWは人工海水を表す．また横方向の運 功には奻果は見られない（B). 
アメフラシ摄食行動における動機づけニューロンとその周辺ネットワーク

類の調節ニューロンの存在が予測できる. 実際, 我々 はP1R-Eとして 3 個, P1R-Dで 4 個, P8Rで 2 個を 同一神経節内に見出している。またこれら調節ニュー
ロンの効果は，放電を何度か繰り返すことにより非常 に大きくなることもわかった．增強効果をもたらす ニューロンの結果を図 6 に示す.

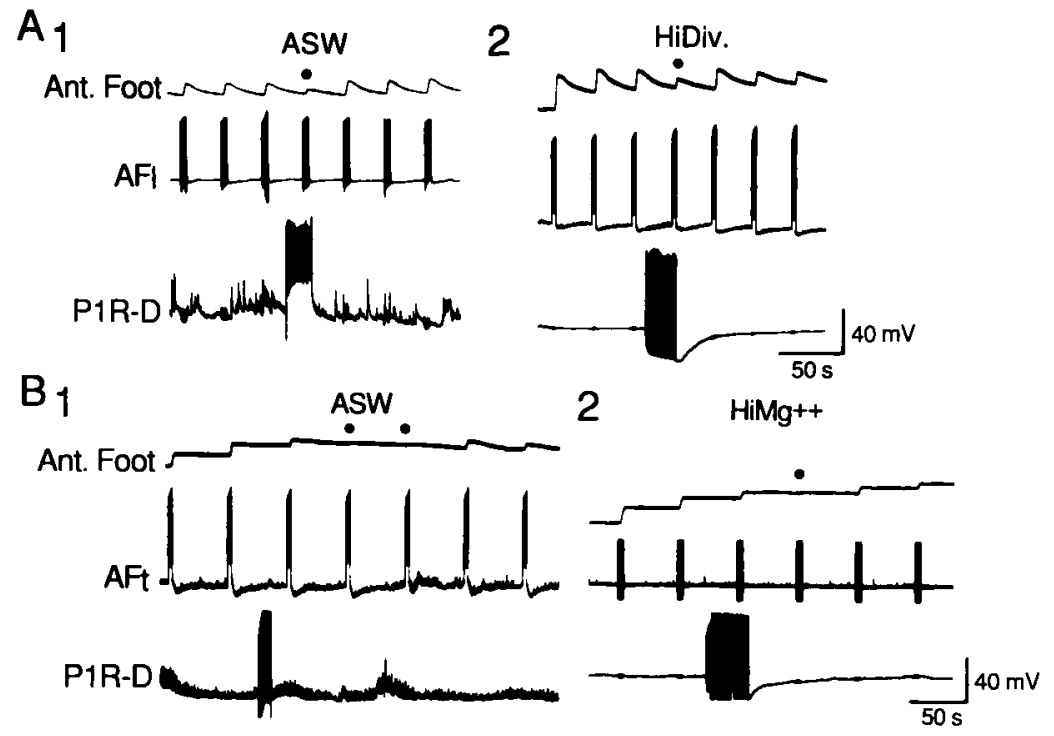

图 5、調節ニューロンP1R-Dによる前腹足運動（A，前後；B，横方向）の抑制奻果 (黑丸部). い すれれも中枢内シナブス結合を抑えた場合 $\left(\mathrm{A}_{2}, \mathrm{~B}_{2}\right)$ も発現し、ニューロンが筋に直接作用する と考えられる.

A

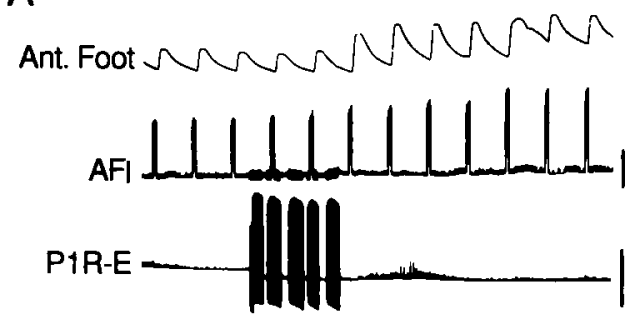

B

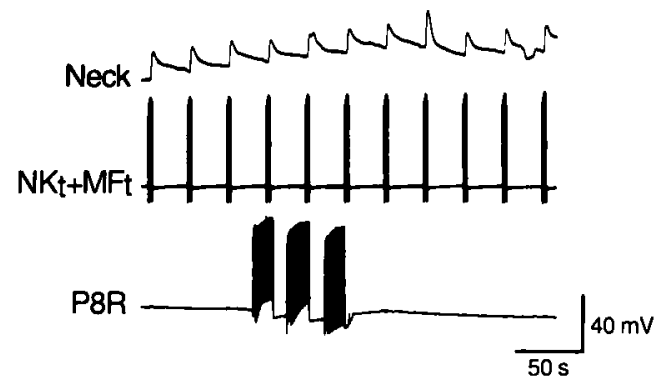

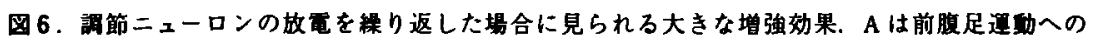
P1R-E の効果, B は首運动への P8R の奻果. 


\section{7. 運動調節の発現機構}

ニューロンによる運動調節の機構としては現在まで 二種類が知られている.一つは運動ニューロンにより 筋に誘発されたJunction potential の大きさを変化さ せるものであり，もう一つはJunction potential の大 きさは変化させず，筋運動のみを修飾するものである， 後者の場合，細胞内メッセンジャー（cAMPなど）を 介して収紑性のみを変化させると考えられ，例として セロトニン含有の調節ニューロン (MCC) がある ${ }^{18)}$.

そこで，今回見出した運動調節ニューロンについて その作用機構を調へてみだ6).17)。その結果, 增強効 果を持つP1R-E, P8R は共に運動ニューロンによって 誘発されるJunction potential の大きさを増大させた. また，抑制効果を持つ P1R-D はその大きさを减少さ せた.これらの結果より，今回同定したニューロンの 調節機構が前者, すなわちJunction potential の大き さを変化させるものであることがわかった．ただこの 場合, 調節二ューロンの Modulator 物質が筋細胞膜側 に作用するものだけでなく，運動ニューロンの末端側 に作用するものも最近報告されている．例えばアメフ ラシの歯舌運動ニューロン内に見つかったBuccalin というペプチドは連動を抑制するが, その時, 運動 ニューロンの末端側に作用して伝達物質の放出を抑え ると考えられている ${ }^{19)}$. したがって P1R-Dの作用に ついてもこのような可能性があるが，まず第一にこれ ら調節二ューロンが放出している Modulator 物質を見 いだす必要がある.

\section{Modulator 物質}

最近, アメフラシの Pedal ganglion 内で二つのタイ プの運動調節ニューロンが見出された. 一つはセロト ニン含有タイプで, アメフラシ (Aplysia brasiliana) の遊泳時, その連動を增強させると考えられてい $ろ^{20)}$ ，残念ながらこの他で遊泳する種はないが, Blankenship らはAplysia califomica ではこれと同種類 の調節ニューロンが歩行運動を增強させる可能性を示 唆している21). 他の一つはPep（pedal peptide）と呼 ばれるぺプチドを含有し, Aplysia califomica の歩行運 動を増強させると考えられている22).

そこで我々は，今回見いだした調節ニューロンのう ち增強効果をもつ P1R-E, P8R がセロトニンもしくは Pepを含有する可能性を抗体染色法を用いて調べてみ た. セロトニン抗体を用いた実験ではネガティブな結 果を得た。一方，Pep抗体を用いた場合は弱く染まる
ことがわかっだ6).17)が, HPLCを用いてニューロン 含有ペプチドを直接測定したところ Pep は存在しな いことが明らかになった.これらの結果, P1R-E， P8R は今まで見いだされている二種類の調節ニューロ ンとは異なるタイプであると考えられ，P1R-D も含 めたこれら調節ニューロンが利用する Modulator 物質 の探索は興味深い.

\section{9. おわりに}

図 7 に今回の研究で明らかになったC-PRによる攝 食姿勢形成のうち，前腹足，首部の運動制御のネット ワークをまとめたまま，C-PR は多シナプス性に運 動ニューロンを興畒，または抑制して基本となる姿势 をとらせる.この時, 首運動ニューロンは大きく興奪 させられ，また前腹足運動ニューロンはその活動が抑 制される. それと同時にC-PR はこれらの部分の運動 調節ニューロンを単シナプス性に興奪させその姿勢を 長期に保持させる.この時, 首の運動は P8Rにより 大きく増強させられる. また前腹足部では動きの方向 により異なり，横方向では P1R-Dのみにより抑制さ れるが, 前後方向はP1R-D の抑制後 P1R-Eにより增 強させられる.このようなネットワークでは, 一つの 目的運動の形成で, 基本となる運動とその調節が別の 経路を通って達成されている，一方，アメフラシ歯舌 運動ニューロンB15, B16では, 伝達物質のアセチル コリンに加えて数種類の運動調節ペプチドを放電に伴 い同時に放出することが知られている(19),23)-25).こ の場合は運動ニューロンが調節ニューロンとしての性 格も持ち, ペプチドの作用は高頻度放電時のみに発現

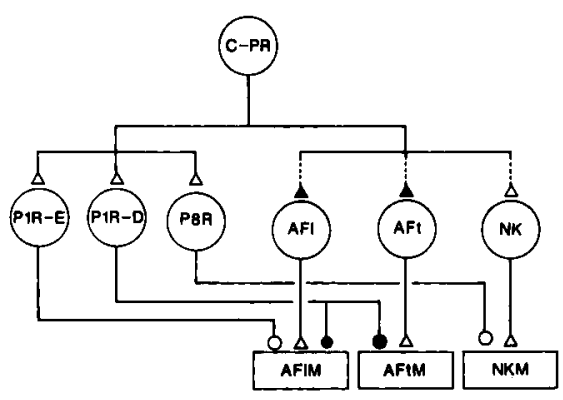

图 7、C-PRによる前腹足，首部の姿拲形成ネットワーク． $A F_{1} M, A F_{t} M, N K M$ はそれぞれ前腹足前後, 横方向 筋および首部筋を示す，図では前腹足部の前後，横 方向，および首の運動を誘発する運動ニューロンを それぞれ $\mathrm{AF}_{1} 、 \mathrm{AF}_{1}$ および $\mathrm{NK} て ゙$ 代表させた．白， 黒三角はそれぞれ興誉性、抑制性シナブス結合を。 また白，黑丸はそれぞれ運動の増強，抑制効果を表 す. 
すると考えられている23).

本稿では私が Kupfermann 研究室の 2 年間で得た結 果を御報告させていただいた．実除の生体内では上記 のような伝達調節機構が, 連動系のみならず中枢の ニューロンネットワーク内で多数使われていることも 最近明らかになっている.種々の行動（もしくは定型 運動）の発現に㗫して、C-PRのような指令ニューロ ンから調節ニューロンへの情報の流れは，基本となる 運動発現ネットワーク内の多数のシナプスの伝達効率 （ある場合には極性まで）をその行動に最適となるよ うに調節している可能性がある.このことは局所的な 回路の研究のみならす，調節系を含めたニューロンシ ステムとしての研究の必要性を示唆する。

\section{文嗝}

1) Teyke, T., Weiss, K.R. and Kupfermann, I. (1990) Sci. ence, $247,85-87$

2) Kupfermann, I. (1974) Behav. Biol., 10, 1-26

3 ) Weiss, K.R., Koch, U.T., Koester, J., Mandelbaum, D.E and Kupfermann, I. (1981) Adv. Physiol. Sci., 23, 305

4 ) Nagahama. T. and Takata, M. (1987) J. Comp. Physiol. A. 161, 799-809

5 ）長演辰文 (1987) 生物物理, 27, 140-144

6 ) Nagahama, T. and Takata, M. (1988) J. Comp. Physiol. A. 162. 729-738

7 ) Nagahama, T. and Takata, M. (1989) J. Comp. Physiol. A, 166, 143-150

8 ) Nagahama, T. and Takata, M. (1990) J. Comp. Physiol. A. 166. 277-286

9 ) Nagahama. T. and Takata. M. (1990) J. Comp. Physiol. A, 167, 1-10

10）長湍辰文 (1990) ハイイオコンピューティング研究戦 略（神沼、甘利、相澤、三輪䋧)，p194-200，サイエ
ンスフォーラム, 東京

11) Kandel, E.R. (1979) Behavioral Biology of Aplysia, Freeman. San Fransisco

12) Rosen, S.C., Teyke, T., Miller, M.W., Weiss, K.R. and Kupfermann, I. (1991) J. Neurosci., 11, 3630-3655

13) Weiss, K.R., Cohen, J.L. and Kupfermann, I. (1978) J. Neurophysiol., 41, 181-203

14) Nagahama, T., Teyke. T., Weiss, K.R. and Kupfermann, I. (1990) Soc. Neurosci. Abstr., 16, 597

15) Nagahama, T., Weiss, K.R. and Kupfermann, I. (投稿 中)

16) Nagahama, T., Weiss, K.R. and Kupfermann, I. (1991) Soc. Neurosci. Abstr., 17, 1592

17) Nagahama, T., Weiss. K.R. and Kupfermann, I. (投稿 中)

18) Weiss, K.R., Mandelbaum, D.E., Shonberg, M. and Kupfermann, I. (1979) J. Neurophysiol., 42, 791-803

19) Cropper, E.C., Miller, M.W., Tenenbaum, R., Kolks, M.A.G., Kupfermann, I. and Weiss, K.R. (1988) Proc. Natl. Acad. Sci. U.S.A., 85, 6177-6181

20) McPherson, D.R. and Blankenship, J.E. (1991) J. Neurophysiol., 66, 1366-1379

21) McPherson, D.R. and Blankenship, J.E. (1992) J. Neurophysiol., 67, 23-28

22) Hall, J.D. and Lloyd, P.E. (1990) J. Neurobiol., 21, 858-868

23) Whim, M.D. and Lloyd, P.E. (1989) Proc. Natl. Acad. Sci. U.S.A., 86, 9034-9038

24) Cropper, E.C., Price, D., Tanenbaum, R., Kupfermann, I. and Weiss, K.R. (1990) Proc. Natl. Acad. Sci. U.S.A., 87, 933-937

25) Cropper, E.C., Tanenbaum, R., Kolks, M.A.G., Kupfermann, I. and Weiss, K.R. (1987) Proc. Natl. Acad. Sci. U.S.A., 84, 5483-5486

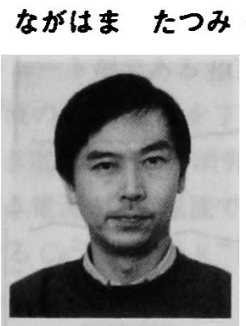

1976年阪大理学部卒. 修士課程修了後, 北大薬学系博士課程（小 畠研）へ.1981年より德島大菌学部助手. 薬学博士. 1990-1992年, コロンヒア大医学部神経行動生物学研究センター研究具. 行動が発 現する神経回路網に興味を持っている．以前は運動発現の基本回路 網だけを扱っていたが，回路網内でのシナプス伝達調節の重要性を 感じて渡米した，米国でのこの分野の進展を考えると日本でもっと 研究者が增えてほしい。

TEL 0886-31-3111 内線5212 